\title{
DUZENTOS ANOS DE “BOM GOSTO”: POESIA, CLAREZA E VERDADE NO ROMANTISMO BRASILEIRO
}

\section{TWO CENTURIES OF “GOOD TASTE”: POETRY, CLARITY AND TRUTH ON BRAZILIAN ROMANTICISM}

\section{Lucas Bento Pugliesi* \\ UFRJ}

Resumo: O presente artigo intenta esboçar a permanência da compreensão setecentista da relação entre poética e política na produção romântica brasileira. Por meio da comparação de retóricas fulcrais para a organização da Razão de Estado em Portugal com as retóricas escritas em português no período pós-Independência do Brasil, espera-se demonstrar as reverberações e permanências em especial no que concerne à aliança entre poesia e ciência. Assim, na última parte do trabalho, busca-se demonstrar como tais concepções duradouras engendraram uma parcela da prática literária romântica, de modo a dar continuidade também a uma concepção utilitária de poesia que servisse ao “Estado”. Por meio de alguns exemplos breves, espera-se demonstrar os modos pelos quais a poesia apropriou os debates retóricos mencionados em vias de gerar um campo literário ambíguo no que tange ideias fundamentais à modernidade literária, como a da autonomia.

Palavras-chave: Romantismo. Poesia Brasileira. Historiografia literária.

\begin{abstract}
The present paper aims to sketch the continuation of an Eighteenth-century conception of the relation between poetics and politics in the Brazilian romantic production. By comparing key rhetoric texts for the organization of the State Reason in Portugal with the rhetoric compendium written in the post-Independence Brazilian territory, we hope to demonstrate the reverberations and permanencies especially in what concerns the alliance between poetry and science. Thus, in the last part of the paper, we discuss how such enduring conceptions engendered a part of the romantic literary practice, to perpetuate also an utilitarian conception of poetry that served to the "State". By means of a few brief examples, we aim to show how poetry appropriated the mentioned rhetorical debates in the process of creating an ambiguous literary field in the context of literary modernity.
\end{abstract}

Keywords: Romanticism. Brazilian Poetry. Literary History.

\section{Poesia, verdade, utilidade e ciência no século XVIII}

Portugal iniciou uma renovação de suas concepções poéticas ainda antes da nomeação de Sebastião José de Carvalho e Melo, o Marquês de

\author{
* Mestre em \\ Literatura Brasileira \\ pela Universidade \\ de São Paulo. \\ Professor Substituto \\ no Departamento de \\ Ciências da Literatura \\ na Universidade \\ Federal do Rio de \\ Janeiro. E-mail: \\ lbentopugliesi@ \\ gmail.com
}


Pombal, como secretário de Estado que reorientaria inteiramente as práticas letradas setecentistas. Nove anos antes de Pombal, em 1746, o padre Luís Antônio Verney publicou $O$ verdadeiro método de estudar, longo tratado sobre questões pertinentes ao ensino, então pensado como substituto do método jesuítico que até então vigorava na metrópole e nas colônias.

Penso que um bom ponto de partida para se situar essa virada no que tange aos valores poéticos apregoados por Verney é discutir o modo como o mesmo percebe o estilo que lhe antecede e a defesa que realiza de uma poesia “útil” (como é útil todo o tratado, conforme já se anuncia desde o subtítulo). De algum modo, a visão negativa da poesia (e da poética) dos Seiscentos e a defesa da utilidade estão intimamente relacionadas e, em última medida, esboçam a transformação do lugar ocupado pela poesia na passagem entre esses dois regimes de temporalidade.

A “Carta Sétima” do referido Método é o momento no qual Verney esboça proposições e definições mais claramente direcionadas à poesia. Segundo o autor, as duas faculdades mentais que governam o fazer poético são o engenho e o juízo (1746, p. 218), sendo a primeira a que se refere à potencialidade de encontrar semelhanças entre matérias díspares, enquanto a segunda, seria responsável por corretamente aplicar essas semelhanças e discriminar as diferenças. Nesse ponto, Verney ressalta que a poesia ibérica que o antecede é composta por um excesso de engenho e de um desregramento no âmbito do juízo. Nessa passagem, o autor especifica que tipo de semelhanças aplicadas à poesia produz o resultado problemático que almeja corrigir:

[...] o falso ingenho consiste na semelhança de algumas letras, como os Anagramas, Cronograms \&c. às vezes na semelhança de algumas silabas, como os Ecos, e alguns consoantes insulsos: outras vezes na semelhanza de algumas palavras, como os Equivocos \&c. finalmente consiste tambem, em compozisoens inteiras, que aparecem com diferentes figuras ou pinturas, como abaixo diremos. (VERNEY, 1746, Tomo I, p. 218-9).

Aqui desponta aquilo que será praticamente um consenso entre os juízos retórico-poéticos da Ilustração em Portugal, isto é, a condenação da engenhosidade vazia associada aos jogos de palavras, trocadilhos, composições em eco e outros recursos amplamente vinculados ao passado, agora tido como obscurantista, da poesia da época da Contrarreforma.

O engenho "bom” que deve arregimentar a poesia proposta por Verney é aquele que encontra semelhanças entre "ideias” e, aristotelicamente, ideias tidas como verdadeiras na medida em que extraídas do saber "racional” à moda da transformação da concepção de "saber” que se operou ao longo do século XVIII. A relação com o conhecimento é evidenciada alguns parágrafos depois: 
Mas a verdade é, que um conceito que nam é justo, nem fundado sobre a natureza das coizas, nam pode ser belo: porque o fundamento de todo o conceito ingenhozo, é a verdade: nem se-deve estimar algum, quando nam se-reconhesa nele, vestígio do bom juizo. [...] os que nam tem ingenho para fazerem, que um conceito brilhe, com a sua própria luz, sem a-pedir emprestada; vem-se obrigados, a procurar toda a sorte de ornamentos, e apegar-se a quaisquer agudezas boas, ou más; para com elas fazerem figura, e parecerem ingenhozos. (VERNEY, 1746, p. 219).

Algumas ideias apresentadas por Verney não são evidentes para o leitor culto do período. Resultante de um longo processo de transformação, o conceito aristotélico de "verossimilhança” é preterido em prol da ideia de "verdade”. Se o paradigma aristotélico separou o impossível crível da verdade, para Verney a imitação de saberes tidos como verdadeiros (associados ao novo paradigma racionalista do método científico) é a própria matéria da poesia e deve guiar o engenho. Na hierarquia objetiva do juízo sobre a poética está, na mais alta conta, a defesa da poesia como veículo de transmissão de conhecimentos sobre os quais recai o foco da elocução em detrimento dos possíveis modos de figuração tópica. Em nenhum momento tal substancialização da verdade é expressa de modo tão claro quanto em um breve comentário sobre a tradução: "se o conceito traduzido em outra língua, conserva a mesma forma; pode-se chamar pensamento ou agudo, ou ingenhozo, segundo as circunstancia: se a-perde, pronuncie V.P. livremente, que é uma ridicularia" (VERNEY, 1746, p.230). A centralidade da transmissão de conceitos de modo a subordinar toda a produção poética ao princípio didático já se entrevê pela própria colocação da discussão em um livro sobre a situação do ensino em Portugal.

Apreciações similares se encontram na Arte Poética de Francisco José Freire, mais conhecido pelo pseudônimo de Cândido Lusitano. Após submeter a "fantasia” ao entendimento, Cândido Lusitano evidencia ao leitor o tipo de semelhança produzida poeticamente que é nociva à verossimilhança e à boa razão, ao comentar um poema de Perez de Montálban afirma: “Seu Author a não formou [esta imagem], segunda a natureza das cousas, nem traz comsigo hum tal fundamento, que a possa fazer parecer verosimil á fantasia, e merecer por isto a aprovação do entendimento.” (1759, p. 122), Na censura se permite entrever que a imagem produzida pela fantasia desenfreada (que Lusitano chama de “cavalo muy fogoso”) nubla o conceito que quer transladar ao invés de evidenciá-lo. Assim o equilíbrio entre fantasia e entendimento ou, em outras palavras, o equilíbrio entre duas das finalidades da poesia, deleitar e instruir ${ }^{1}$, é quebrado em favor do primeiro polo da oposição. Essa linha de pensamento produz resultados divertidos, na medida em que Lusitano tenta levar ao limite lógico as proposições imagéticas dos poetas que desprestigia em vias de provar sua absoluta ausência de valor:
1 "Pode-se dizer, que a Poesia, ou a Poetica, em quanto he Arte imitadora, e compositora de Poemas, tem por fim o deleitar; e que em quanto he Arte subordinada á Filosofia moral, ou Politica, tem por o utilizar a alguem” (FREIRE, 1759, Tomo 1, p. 29) 
Ora não só he pouco verosimil, mas totalmente cousa desproporcionada a accão, que o Poeta lhe attribue. O Ceo se tivesse alma, nunca entenderia, que somente nos seus imensos espaços (que tanto quer significar com a metáfora pouco bem considerada do papel) he que poderia caber o nome daquele Heroe (1759, p. 122-123).

No poema em questão, faz-se um encômio dos feitos do grande herói, assinalando que esses somente seriam suportados pelo infinito do céu que é figura de um grande livro cósmico. Como se nota, Cândido Lusitano não é menos absurdo que a poética da qual quer se desvencilhar ao conjecturar como o céu pensaria a respeito de tal matéria se tivesse efetivamente alma e fosse um ser animado, portanto. Há um modo próprio, ao cabo, em empregarem-se conceitos impróprios, isto é, para o autor é perfeitamente plausível tomar céu como metáfora para um livro, o desproporcional é conjecturar (equivocadamente) sobre a consciência do céu. O acúmulo de imagens como que enovelaria as semelhanças de modo a perder de vista a instrução que se quer transmitir.

Lusitano ainda condena os poemas puramente filosóficos como enfadonhos e possivelmente obscuros para o leitor, de modo que a fantasia é sim desejável, desde que a serviço do entendimento ou ainda do desvelar de um conceito (1759, p. 49).

Contra aquilo que enxergam como primazia da fantasia (desenfreada), os retóricos do século XVIII instituem um "bom gosto” que diz respeito ao equilíbrio, ou em alguns casos, ao predomínio da função didática e civilizatória da poesia. Conforme evidencia Joaci Pereira Furtado em estudo dedicado ao tema, trata-se de uma reconfiguração político-retórico no campo da distribuição dos lugares de produção e recepção:

Assim, o "bom gosto” pode ser apreendido não apenas no âmbito meramente técnico da produção de determinados efeitos discursivos, mas também e, sobretudo, como componente de uma intervenção política que se pretende exercer por intermédio da arte. Assim como no século XVII a agudeza foi padrão distintivo dos "melhores”, no XVIII o "bom gosto" evidencia a civilidade dos que têm "juízo”. Civilidade necessariamente antijesuítica, sob Pombal - cuja meta a ser alcançada, na reforma das letras, será exatamente o "bom gosto”. Na época pombalina, o "bom gosto" é, ao mesmo tempo, ideal a ser atingido e índice de distinção do letrado adepto das mudanças promovidas pelo ministro de d. José I. (FURTADO, 2017, p. 10).

Elabora o comentador, de modo eloquente, a relação intrínseca entre a poética e o projeto civilizatório que se almeja implantar. Contra a "agudeza” seiscentista que pressupõe o engenho da recepção de alguns eleitos (letrados educados pelo modelo cortesão), a “clareza” apregoada por Verney, Cândido Lusitano (e diversos outros) fala de perto aos fins didáticos de uma instrução ampliada que tem em vista o "povo”. 
Referência nominalmente citada por Lusitano, o historiador italiano Ludovico Muratori (1672-1750) clarifica os termos da discussão ao estabelecer de modo cristalino a relação entre poesia e saber e, a partir disso, a participação do poeta na educação cívica. Para o autor, a poesia e a ciência possuem um mesmo objeto, a verdade:

Voltemos nosso estudo para a consideração daquele Belo que se funda principalmente sobre o Verdadeiro e que deleita o nosso Intelecto, porque o Belo Poético, propriamente recai sobre essa espécie. Nem isso parece estranho, porquanto, conforme dissemos, a Beleza das Ciências Especulativas funda-se sobre o Verdadeiro, e conquanto a Poesia não tenha o privilégio de ser incluída entre as Ciências, ela é porém, uma Arte nobilíssima e não menos do que aquela fala ao intelecto [...] (MURATORI, 2014, p. 975).

Conforme esclarecerá o autor, ainda que o objeto seja o mesmo, há divisões sutis que separam ciência e poesia. Cada ciência se ocupa, para Muratori, de um saber específico, o celeste (teologia), o mundano (filosofia) e o material (ciências naturais) (MURATORI, 2014, p. 975), enquanto a poesia pode se ocupar de todos. A ciência opera de modo intensivo, a poesia, extensivo. Pelo potencial exclusivo de produzir deleite no público, a poesia ocupa o nicho de transmissão de um conjunto de saberes intermediários que não dizem respeito à investigação mais complexa das ciências. E para além, o próprio deleite da poesia é efeito que tem na verdade sua causa:

Assim, a Beleza interna, verdadeira e essencial da Poesia é aquela que é conhecida e saboreada pelo Intelecto. Ao ouvir, ao ler um Belo Poema, nosso Intelecto se compraz em um singular deleite, que aliás não nasce senão do reconhecer aquela Beleza com a qual está ornado e vestido o interno Verdadeiro do Poema. (MURATORI, 2014, p. 975).

O ornamento, produtor do deleite, aparece metaforicamente como indumentária da verdade; a poesia, portanto encapsula um conhecimento e o oferece em versão mais palatável ao leitor que se compraz na identificação do conceito. Muratori, ainda que não o diga, oferece uma clara restrição a Aristóteles em sua separação pormenorizada entre verossímil e verdadeiro. Mais intensamente do que Cândido Lusitano, o tratadista entende a clara hierarquia entre "entendimento" e "fantasia”, subordinando esta àquela, de modo que se infere como, a partir daí, a poesia servirá para dar a ver a verdade partilhada com a ciência.

Essa reconfiguração do lugar da poesia que agora se irmana com a ciência se coaduna aos comentários sobre a instrução do poeta realizados por Cândido Lusitano:

[...] o estudo das Leys não deve ser desconhecido do Poeta, por ser huma principal causa da vida civil, e como tal lhe pertence muito, por ter por fim o instruir. [...] não deve ignorar a Arithmetica, a Optica, a Dialectica, nem 
ainda a Medicina, de que tudo achamos exemplos nos dous Principes da Poesia Grega e Latina [...] (FREIRE, 1759, Tomo 1, p. 48-9).

Apoiando-se na imitação das grandes autoridades, Cândido Lusitano entrega como dado uma inversão da velha restrição platônica à poesia. No Íon o poeta é aquele que fala sem deter a propriedade de falar, isto é, aquele que desconhece o conceito sobre o assunto, aproximando-se, portanto do sofista. Especularmente, o corpo do poeta engendrado no século XVIII de Lusitano é aquele que tudo precisa saber como parte da paideia básica no que concerne o fim último da poesia, o instruir. Acompanhando Muratori, poesia e ciência lidam com o mesmo objeto, a verdade, para diversos fins, transmitir e conhecer, respectivamente.

\section{Reverberações do “bom gosto” em poéticas e retóricas oitocentistas}

Conforme aponta o mapeamento de Roberto Acízelo (1999) em $O$ Império da Eloquência, o ensino de poética e retórica marcou os estudos preparatórios dos currículos secundários nacionais a partir da fundação do Colégio Pedro II. Segundo o autor, o rígido modelo proposto pelo Colégio teve consequência imediata, fazendo as vezes de um programa nacional de ensino, na medida em que foi adotado em uma grande quantidade de instituições de ensino secundário em todo território brasileiro. ${ }^{2}$ Assim, como o próprio autor sugere, as diretrizes de ensino traçadas pelo Pedro II tiveram impacto direto no processo de desenvolvimento cultural mais amplo, sem restringir-se, portanto, aos próprios formandos.

Isso posto, chama a atenção em especial a organização curricular, que até a reta final da década de 1860, contemplou as disciplinas de retórica e poética em detrimento do ensino específico de "literatura” (ACÍZELO, 1999, p. 33). De modo inversamente proporcional, o declínio dos estudos de poética e retórica foi compensado pelo alvorecer da institucionalização de noções de história da literatura nacional em um processo contínuo somente efetivado no período republicano.

Como um levantamento ulterior, Acízelo estabelece quais compêndios de retórica e poética foram utilizados como material de apoio ao longo da fase imperial. Acompanhando-o em suas observações, penso que é lícito pensar que os referidos compêndios tiveram relevante impacto na formação literária dos letrados do Império que se consolidava. Por um lado, a análise desses compêndios revela algo da visão institucional do ensino de letras em seu projeto sistêmico; por outro, torna-se possível rastrear nos espécimes de crítica literária engendrados no período traços dessa matriz retórica fundadora. Assim, para evitar, romanticamente, o apagamento dessas concepções históricas, é o caso de precisar quais prerrogativas retórico-poéticas foram endossadas por esse vasto corpus.
${ }^{2} \mathrm{O}$ autor enumera a lista completa: "diversos estabelecimentos se constituíram à imagem do Pedro II, como, por exemplo: o Colégio Stall, o Abílio, o Meneses Viera, o Progresso, o Externato Aquino (Rio de Janeiro); os Colégios do Caraça, de Campo Belo e de Congonhas do Campo (Minas Gerais); o Colégio São Pedro de Alcântara (Petrópolis); o Ginásio Baiano e o Colégio São João (Bahia); o Colégio São Luís e o da Sociedade Culto à Ciência (São Paulo); o Ateneu Sergipano" (ACÍZELO, 1999, p. 32-33) 
Principio a discussão por Lições Elementares de Eloquência Nacional (1840) e Lições de Poética Nacional (1851) do padre português Francisco Freire de Carvalho, dos mais antigos compêndios que circularam no Brasil durante o Oitocentos. Em sua explanação da função da poesia (e do discurso), Freire de Carvalho já se aproxima às concepções em voga ao longo do século anterior:

O fim principal, que deve propor-se assim a Poesia, como todo e qualquer gênero de composição, é fazer no espirito dos leitores, ou ouvintes uma impressão útil. A poesia, considerada em geral, produz estas impressões empregando meios indirectos, quaes são, a fábula, a narração e a representação dos caracteres. (1851, p. 74-5).

A passagem está presente em capítulo dedicado ao gênero didático, assim, ao invés de pensar o gênero em questão como parte de um todo poético, é a poesia que se submete a ele. A essa altura, sem novidades consideráveis, Carvalho se subscreve à antiga lição da utilidade, sem que se possa entrever algo de específico. Entretanto, a iteração da instituição do "bom senso" é notada em uma série de juízos empregados pelo autor tanto no âmbito dos gêneros poéticos, quanto no dos estilos.

Ao discutir a forma da mista que nomeia "tragicomédia”, o autor efetua, aristotelicamente, uma gradação de estilo para situá-la entre o elevado da tragédia e o rebaixado da comédia, de modo a alinhavar um decoro próprio ao gênero que seria ignorado por seus detratores. Ainda assim, a tragicomédia só será pertinente conforme obedecer indicações mais largas que condicionam todos os gêneros discursivos:

Podendo igualmente dizer-se, que seja qualquer que fôr a fórma, com que o Drâma fôr apresentado sobre o Theatro, isto é, seja qualquer que fôr o tom, alegre, ou sério, ou ja misto, de que elle se revista: deverá sempre julgar-se, que a humana sociedade, na qual taes composições apparecêrem, faz notáveis progressos na marcha da verdadeira civilização: com tanto que dos espectaculos dedicados para recreio, e para instrucção do Publico, se remova tudo quanto pode ofender o pudor e a decência, ou, geralmente falando, tudo quanto mostrar tendencia para a imoralidade. (CARVALHO, 1851, p.152-153).

A moralização não é surpreendente de forma alguma, mas dá a ver a relação imediata entre o recreio teatral e sua função civilizatória; a imoralidade é particularmente danosa no caso do teatro na medida em que este é o instrumento do progresso por excelência. A performance teatral, diferentemente do escrito em livro, abre-se à comunidade, ao público amplo, de modo que pode servir tanto como ferramenta cultural imprescindível (algo que na passagem se justifica pela lição histórica), quanto como veículo de contaminação da mente popular com imoralidades. A teorização anda bem acompanhada dos escritos do teatro moral francês que se desenvolvia àquela 
altura e que encontrariam lastro nos anos subsequentes no projeto teatral de José de Alencar e outros mais.

Até aqui, portanto, Freire de Carvalho dá mostras do bom senso burguês, mas não especificamente do bom gosto que se revela efetivamente em comentários acerca da construção da imagem na poesia que, como discutido, é o principal vetor sobre qual incide a crítica da Ilustração portuguesa dos estilos seiscentistas. Ao glosar os vícios das metáforas, o tratadista lembra que a dessemelhança é um dos principais na medida em que propõe relações entre particulares muito afastados, algo que exclui de princípio a poética contrarreformada da agudeza (1840, p. 99-100). A dessemelhança parece se coadunar ao estilo "asiático” que é “[...] verboso, empolado, e vão, excedendo muito a exacta e escrupulosa proporção entre as ideas, e as palavras" (1840, p. 184); em vias de que se permite entrever a partição entre juízo e engenho proposta pelos tratadistas setecentistas que enxergam uma adequada proporção entre pensamento e elocução. Portanto, a semelhança artificial e a desproporção são as principais causas do vício na eloquência (e na poética), na medida em que obnubilam ou confundem o pensamento, desviando o leitor da correta apreensão do dito. Algo que se conforma, em última instância, na condenação de um tipo particular de figura de palavra também rejeitado por Verney:

Consiste a Figura Antanaclasis no uso de vocábulos, que levemente alterados significão cousas diversas; taes são as palavras, que pelo simples acrescentamento de preposições mudão de significação [...] É de advertir, que o uso muito frequente destas Figuras, as quaes as mais das vezes consistem em verdadeiros trocadilhos de palavras, e que estiveram muito em voga nos séculos do máo gosto da Eloquencia, é sinal de um espirito ocioso, baixo, ocupado em bagatelas, e por tanto falto de juízo, e de bom gosto. (CARVALHO, 1840, p. 158).

Aqui nominalmente estão postas as categorias setecentistas do bom gosto e do juízo, de modo que a censura não incide na prática discursiva em si, mas atrela ao discurso, um lastro de pensamento. A despeito da aparência gratuita de invectiva ad hominem, o comentário elucida a relação direta entre discurso e verdade: ao falar através de trocadilhos, o orador dá sinais de um pensamento comezinho orientado por joguetes lúdicos e não pelo ideário racional e retilíneo. A compreensão da criação poética permanece inalterada em suas consequências - a necessidade da transparência da eloquência como modo de dar a ver a verdade - e em seus ajuizamentos. Mesmo depois de duzentos anos, Freire de Carvalho faz questão de pontuar a distância do “século do mau gosto” e de suas práticas.

A associação entre conceito e discurso, passando ao largo das discussões pós-kantianas acerca da arte, pode ser rastreada mesmo em um compêndio nitidamente mais preocupado com a proposição de ideias “autorais” como Elementos de Retórica Nacional (1869) de Junqueira Freire. Há uma 
subseção em seu tratado preocupado em discernir a eloquência verdadeira da falsa, onde declara: "A elocução oratória não consiste em uma verbiagem ociosa: ella não é o anhelo por fallar, mas o anhelo por persuadir: ella não aspira a um triumpho scintillante de palavras inanimadas, mas a um triumpho complementar de pensamentos profícuos. " (FREIRE, 1869, p. 39).

A persuasão deve ser produzida quando as palavras são animadas por um espírito. O ânimo discursivo é complementar ao pensamento profícuo, demonstrando mais uma vez a relação hierárquica que pressupõe uma verdade que esteja subjacente à organização em discurso. Não obstante, Junqueira Freire especifica ao leitor o tipo de verdade da qual está tratando ao homologar a figura do sábio à do poeta (e do orador), calcando-se na autoridade do “geômetra D’Alembert” que condensaria os dois arquétipos. No mais, é válido notar como Freire se equilibra entre um conjunto de referentes heterodoxos, ora apoiando-se em concepções de poética clássica, citando sem distanciamento histórico a Santo Agostinho - relembrando a definição de eloquência como a verdade que prova, move e ensina (FREIRE, 1869, p. 6) -, ora produzindo enunciados decididamente afinados com a ruptura moderna:

O romantismo legitimo não posterga as normas do bom gosto: só não curva-se á prepotência de alguns preceitos arbitrários: só não obedece a imposições despóticas, ainda que venhão de Aristoteles. Não segue as regras de Quintiliano, porque são de Quintiliano, segue-as, em quanto harmonizão-se com a razão. Não destróe, mas tambem não continua a edificar os templos dos clássicos, para que o Ciceros futuros não sejão somente os Ciceros passados, para que os Virgilios, que hão de ser, possão ser mais que os Virgilios, que forão, para que o mundo literário não limite-se a um circulo vicioso para todo o sempre. (FREIRE, 1869, p. 75).

Ao afirmar a independência da tradição e o rompimento com o costume, oferecendo o senso crítico como veículo para se chegar às melhores formulações no campo da eloquência, Junqueira Freire torna possível perceber como, entre todas as ruínas do passado, o vínculo entre discurso e utilidade permanece como fronteira incontornável. De um lado, há o elogio da originalidade e uma concepção nacionalista que prevê uma formação cultural, conforme a sedimentação conceitual romântica; de outro, como mola anterior e contra a lição estética de Kant, a poesia ainda é útil, a despeito de não seguir um conjunto de regras preconizadas pelo costume.

Mais próximo da ortodoxia setecentista está o tratado de Manuel da Costa Honorato que, já desde a abertura, entende que a poesia:

Exercita nossa razão sem fatiga-la, cobre de flores o caminho das sciencias, e proporciona um agradavel entretenimento depois das penosas tarefas á que é preciso submeter se o espirito, que deseja adquirir erudicção, ou investigar verdades abstractas [...] Ella serve para marcar o caminho das paixões e da fantasia, para dirigi-las sem inutilizar seo vôo, para pôr-nos 
á vista os precipícios em que outros se despenhárão, e em que poderemos cahir, si não formos bem sustentados pela critica, e guiados pelo bom gosto; e finalmente serve para admirar as belezas, não deixar-nos deslumbrar com a falsa eloquência, e habituar-nos a que nossos sentimentos vão sempre de acordo com a filosofia. (1870, p. 9-10).

O excerto do capítulo um de Sinopses de eloquência e poética filia imediatamente a poesia à utilidade, de um ponto de vista bastante específico, isto é, sua função é como que preparar o caminho para o saber científico ou ainda, recrear a mente, atribuindo-lhe o devido descanso diante do peso da abstração. De um lado, a instrução é recoberta por um caminho de flores, atualizando a metáfora do deleite conforme em Muratori; de outro, o deleite propriamente dito é uma atividade necessária para permitir o exercício da razão, como seu complemento - o que já dá a ver a relação entre trabalho e lazer, proposta por um modelo cívico burguês.

A introdução faz vezes de síntese, na medida em que toda a concepção poética de Honorato (enunciada de um ponto-de-vista universalista) se faz presente. Como em Cândido Lusitano, a poesia pode guiar as paixões e a poética pode deslindar os modelos ruinosos do passado, aquilo que o autor nomeia sob a égide de "falsa eloquência", categoria operacional que se opõe nominalmente ao "bom gosto", também diretamente associado à filosofia. Nesse sentido, também acompanhando Lusitano a “falsa” expressão dá a ver um pensamento igualmente falso (ou deficitário), assim que o "bom gosto” é proporcional e adequado à filosofia, em última instância, à verdade. Como não poderia deixar de ser, tais aspectos transparecem em seus comentários acerca da elocução:

As melhores expressões se contêm na essencia mesma das cousas, e se nos patentéão por sua própria luz; quando tivermos no espirito uma idéa clara, justa e precisa, o termo, para significá-la, oferecer-se-há por si mesmo, e seguirá o pensamento, assim como a sombra segue o corpo. [...] Por isso todas as vezes que o orador mostrar grande empenho em affectar a elocução com termos exquisitos e extravagantes cairá em um vicio em logar de virtude, por mostrar em excesso a arte que emprega, visto que deve ser o caracter habitual uma linguagem natural, simples e expressiva. (HONORATO, 1870, p. 54).

A linguagem deve acompanhar a natureza da matéria, sem afetações que possam turvar o sentido, remediando assim o excesso em prol de um estilo ático, de modo a atualizar a antiga bula retórica que afasta os termos raros (e/ou barbarismos). Na esteira da relação entre matéria e imagem, Honorato pensará a “metáfora” a partir de um viés metafísico, como sendo a propriedade de linguagem que permite materializar o incorpóreo ou ideal - “exprime por imagens sensíveis tudo quanto é relativos ás faculdades d'alma, dá corpo aos objetos abstractos” (HONORATO, 1870, p. 79-80). 
De um lado, está a euidentia de Quintiliano, a enargeia grega que coloca o objeto diante de olhos imateriais, isto é, dá a poesia a potencialidade de fazer ver conceitos abstratos, o que conformaria o gesto de "encapsular" ou "recobrir de flores” um conhecimento esquivo. Apesar do elogio geral à metáfora, Honorato acompanha Freire de Carvalho nas restrições a essa figura de linguagem que podem degenerar em "viciosas por três modo: excesso, má escolha e dissimilhança” (HONORATO, 1870, p. 79-80).

Os juízos do frade português são reproduzidos também no que tange à restrição à tragicomédia, enquanto gênero misto e indecoroso (1870, p.128) e aos efeitos poéticos decorrentes da consonância, que, uma vez mais associados à falsa eloquência seriam fruto da "falta de discernimento de quem se occupa de bagatellas” (1870, p.113). O que demonstra que seu compilado em muito reaproveita as ideias de seus predecessores, já em momento tardio da discussão do tema, chegando, como no caso da discussão das metáforas a reproduzir juízos ainda mais ortodoxos do que aqueles que circularam entre a geração anterior. De todo modo, demonstra-se certo consenso no que tange ao estilo valorizado - da metáfora regulada pela natureza da matéria, sempre se prestando à clareza e ao didatismo -, assim como o rechaço das formas agudas de construção imagética no que se conformaria como "bom gosto” enquanto categoria auxiliar de uma poética complementar à poesia e à ciência, entendidas como metodologias válidas da busca pela verdade.

\section{Entre poética e estética}

Algo que não pode ser sumariamente ignorado no que tange a discussões acerca de permanências é a inegável descontinuidade também implicada nesses processos. Apesar da possibilidade, enquanto proposta de trabalho, de se mapear as reiterações de juízos setecentistas em poéticas do século XIX, não se pode descartar que além de Verney, Cândido Lusitano, Muratori, Quintiliano ou Horácio, os compiladores de retóricas oitocentistas conheceram também Hugh Blair, frequentemente citado nas introduções das referidas obras. Como bem apontou Eduardo Vieira Martins, em trabalho dedicado às fontes poético-retóricas da obra de José de Alencar, Blair estaria a meio de caminho entre a concepção mimética-pragmática setecentista e algo da expressividade da arte romântica, trazendo um vetor de novidade para as discussões de poesia. Conforme o comentador:

[...] no momento em que define a essência da poesia Blair se afasta da tradição crítica e desloca o foco da atenção do efeito produzido pelo poema para a pessoa do poeta, movimento que, dentro do esquema interpretativo proposto em The mirror and the lamp, anteciparia a passagem de uma estética pragmática, dominante no século XVIII, para as teorias expressivas do romantismo. De fato, Blair inicia a análise da natureza da poesia refutando seu caráter ficcional e imitativo.” (MARTINS, 2003, p. 19-20). 
Ainda assim, Blair não se desprende de certa doxa no que concerne ao comentário acerca das imagens em poesia. Como anota Martins, Hugh Blair ainda condena os usos ornamentais (associados à retórica escolástica dos séculos anteriores) subordinando-os à argumentação, dando ênfase em suas Lições de Retórica à elocutio e não, como a prática usual, a um inventário de tropografia (MARTINS, 2003).

A arte que Blair pretende apresentar ao seu público é descrita como contrária aos jogos falaciosos de palavras que deram lugar a tantos preconceitos contra a retórica. Já na primeira lição, depois de louvar a importância do discurso e dos esforços das nações civilizadas para aprimorá-lo, distingue a má e a boa retórica, defende a segunda das críticas que lhe eram feitas e propõe um estudo orientado pelos 'principles of reason and goodsense". (MARTINS, 2003, p. 16).

Tal aspecto se torna nítido em longo capítulo dedicado à metáfora. Neste contexto, Blair instrumentaliza a figura de linguagem do ponto de vista subjetivo da recreação, em sua concepção, perceber as semelhanças entre objetos insuspeitos é marca da linguagem humana por fazer “a mente, então em funcionamento, exercitar-se sem fadiga, ao mesmo tempo em que é gratificada pela consciência de seu próprio engenho”3 (BLAIR, 1787, p. 373, vol 3). Reproduzindo o juízo do costume, a figura não encontraria rival, em "fazer ideias intelectuais, em certo sentido, visíveis aos olhos, ao dar-lhes cor, substância e qualidades sensíveis” ( BLAIR, 1787, p. 375). Contudo, como alerta o autor, seu uso deve ser cuidadoso porque à sombra da "menor imperícia, encontramos-nos sob o risco de introduzir a confusão no lugar de perspicuidade” (BLAIR, 1787, p. 375). Para evitar tal impropério, o escritor do compêndio apresenta um conjunto de regras para o correto emprego metafórico que perpassa pela adequação entre a metáfora e a natureza do objeto representado (imagens elevadas para objetos elevados etc), homologia semântica do campo da representação (glosa horaciana da prerrogativa da ausência de mistura), ausência de mescla entre o discurso figurado e não figurado e, conforme nos interessa mais de perto, o rechaço do acúmulo de metáforas, do encontro entre duas imagens distintas na mesma sentença e da aproximação de objetos por demasia disparatados ( BLAIR, 1787, p. 378-393).

[...] é preciso tomar precaução adicional para que a semelhança, que é o fundamento da metáfora, seja clara e nítida, nem extravagante, nem difícil de descobrir. A transgressão desta regra produz metáforas chamadas “duras" ou "forçadas" que são sempre desagradáveis, porque intrigam o leitor e, ao invés de ilustrar o pensamento, deixam-no perplexo e intricado. (BLAIR, 1787, p. 382-3, trad. livre) ${ }^{4}$

Como a passagem deixa entrever, as regras visam produzir efeito similar na elocução aos apregoados por Verney e Cândido Lusitano a partir
${ }^{3}$ Tradução livre: No original: "The mind, thus employed, is exercited without being fatigued; and is gratified with the consciousness of its own ingenuity”.

${ }^{4}$ No original: “[...] particular care should be taken that the resemblance, which is the foundation of the Metaphor, be clear and perspicuous, not farfetched, nor difficult to discover. The transgression of this rule makes, what are called, harsh or forced Metaphors, which are always displeasing, because they puzzle the reader, and, instead of illustrating the thought, render it perplexed and intricate." 
de Muratori, isto é, na visão de Hugh Blair há um vetor utilitário na metáfora que deve dar a ver o conceito, "ilustrar" ideias intelectuais ou ainda, como mantido pela etimologia, possibilitar a des-coberta de uma ideia. Assim, de suas prerrogativas, Blair afasta qualquer sobreposição que tornaria, ao leitor, indiscernível a passagem entre os registros figurado e literal. Como exemplo dessa má eloquência, o professor de retórica cita nominalmente Abraham Cowley e outros poetas de seu tempo, evidentemente referindo-se às poéticas do século XVII que teriam considerado esses usos forma de agudeza (wit) e engenho, havendo aí certo gosto em não ser compreendido.

Ao contrário da agudeza dos eleitos, Blair endossa a clareza que fale a todos de uma poesia que, se preocupada com certa originalidade subjetivista como defende Eduardo V. Martins a partir de M.H. Abrams, ainda retém uma função muito evidente de delinear contornos visíveis e discerníveis para o público, atuando em última instância como auxiliar da boa razão, entendida como aquela utilitária, oponível ao raciocínio agudo desregrado, preocupado apenas em encontrar os píncaros da raridade elocutiva.

O que expõe ainda Martins (2003) é a manutenção do princípio do "bom senso”, basilar para se pensar a construção imagética contra os excessos dos seiscentos e as quimeras da sua fantasia. Na compreensão de teóricos do século XVIII como Hugh Blair e Cândido Lusitano, o estilo agudo dos séculos XVI e XVII colocaria o ornamento num grau de importância mais elevado do que os contornos formais, fundamentais para o entendimento, fim último da representação. A aproximação de elementos distanciados semanticamente ${ }^{5}$, conforme a compreensão desses tratadistas, em nada contribuiria para a silhueta de formas bem definidas que sirvam a um propósito didático, da razão e do bom senso.

Mas não apenas os tratadistas oitocentistas se mostraram tributários do pensamento de Hugh Blair, também Immanuel Kant cita o professor escocês em passagem de A antropologia de um ponto de vista pragmático (2007, p. 351) e o faz, precisamente, quando discute a natureza da poesia, enquanto um discurso animado pelo espírito para o qual a versificação (uma forma com conformidade afim, mas sem fim) é imprescindível. Nesse sentido, ao eleger Blair como possível autoridade no tratamento das belas artes, Kant, talvez, nos permita pensar em que medida em suas considerações sobre estética não estaria reiterada a aludida concepção de bom gosto.

Para tentar endossar essa proposta de leitura, penso que um caminho possível seria refletir sobre as considerações do filósofo acerca dos juízos de gosto puros, isto é, sem a interferência do prazer sensorial (sempre contingente). Kant trata da questão na "Analítica do Belo", parte inicial da Crítica da Faculdade do Juízo (2008). O comentário, apesar de breve, é relevante tendo em vista que a teoria romântica pós-kantiana privilegiará uma visão “expressiva”, por assim dizer, da arte e da poesia, entendendo a forma como
${ }^{5}$ Para uma arqueologia completa sobre o tema, ver HANSEN, João Adolfo. "Barroco, neobarroco e outras ruínas" em Revista Teresa, São Paulo, n. 2, p. 10-68, 2001. 
conformação anímica de uma substância transcendente, precisamente, o aludido “espírito” da poesia.

Segundo a teoria estética de Kant, o objeto belo ao ser contemplado desautomatiza a estrutura normal do funcionamento da mente. Equipada da razão, a mente espontaneamente estabeleceria relações de causalidade, assim como aplicaria uma compreensão prévia de espaço e tempo a todos fenômenos experimentados pelos sentidos. $\mathrm{O}$ entendimento seria uma faculdade inata que, portanto, diria respeito a uma estrutura formal que organiza os insumos exteriores de modo compreensível. O momento estético da contemplação como que colocaria em suspenso, num primeiro momento, a faculdade do entendimento, despertando a mente para aquilo que Kant chama de estado de livre jogo entre faculdades do juízo e do entendimento, o que configuraria a reflexão imotivada, na qual a mente não atua seguindo sua rotina costumeira.

O prazer da contemplação estética, explica o autor, advém da descoberta, por parte da mente, de seu próprio processo automático (e imperceptível). Ao delinear, pela imaginação, os contornos de um objeto belo, a mente percebe o próprio modo como frequentemente delineia contornos nos objetos externos. Como organiza o caos da Coisa-ela-mesma (o mundo exterior) em fenômenos perceptíveis. Ao perceber a harmonia dos contornos do objeto particular por intermédio do juízo, a mente afina-se com a maneira pela qual harmoniza os objetos exteriores, por intermédio do entendimento, enquanto potência humana universal. De modo talvez mais claro, em um de seus textos pré-críticos, Kant entenderá que a imaginação produzirá como que uma “vivificação” das representações apreendidas pela faculdade do entendimento (KANT, 2015).

Assim, para sua teoria da contemplação, os contornos seriam fundamentais, enquanto as cores e o preenchimento, meros acessórios. O que produziria as cores, no âmbito pictórico, seria o efeito de "atração", contribuindo para o potencial de sedução do objeto, aspecto subsidiário no que tange ao juízo de gosto.

É um erro comum e muito prejudicial ao gosto autêntico, incorrompido e sólido, supor que a beleza, atribuída ao objeto em virtude de sua forma, pudesse até ser aumentada pelo atrativo; se bem que certamente possam ainda acrescer-se atrativos à beleza para interessar o ânimo, para além da seca complacência, pela representação do objeto e, assim, servir de recomendação ao gosto e à sua cultura, principalmente se ele é ainda rude e não exercitado. Mas eles prejudicam efetivamente o juízo de gosto, se chamam a atenção sobre si como fundamentos do ajuizamento da beleza. (KANT, 2008, p. 71, Parágrafo 14)

Os juízos de gosto (falsos) com base na avaliação empírica podem contribuir para os juízos de gosto autênticos conquanto atraiam em direção ao 
objeto belo - aquele condicionado por uma conformidade afim, sem conceito e sem finalidade -, mas se chamarem atenção sobre si causarão desserviço ao cultivo da faculdade do juízo e ao gosto, enquanto categoria universalmente válida. Tendo este aspecto em conta, para tratar especificamente do âmbito poético, poderíamos pensar as considerações de Kant na Antropologia de um ponto de vista pragmático no que se refere à oposição entre a agudeza (witz) e a faculdade do juízo. A agudeza seria uma propriedade do entendimento (2007, p. 325-6, Parágrafo 54) que encontraria semelhanças entre objetos heterogêneos e os subsumiria em determinado gênero; a faculdade do julgamento determinante, por sua vez, seria mais estrita, ao necessariamente subsumir um particular a um universal específico.

Sem desconsiderar a radical revisão do conceito de “juízo”, conforme proposta pela Terceira Crítica, é possível entrever os termos da discussão permeiam o sulco das poéticas setecentistas previamente citadas, ainda que não necessariamente com alusão as mesmas concepções. Nesse sentido, Kant é menos estrito do que seus contemporâneos e encontra lugar para a agudeza entre o cultivo das faculdades cognoscíveis, entretanto o filósofo põe reparo aos abusos (e despropósitos) da propriedade:

[...] Wit goes more for the sauce; the power of judgment, for the sustenance. To hunt for witty saying (bons mots), such as the Abot Trublet richly displayed, and in doing so to put wit on the rack, makes shallow minds, or eventually disgusts well-grounded ones. [...]Wit in wordplay is insipid; while needless subtlety (micrology) of judgment is pedantic. (KANT, 2007, p. 326, Parágrafo 55).

Na passagem, o filósofo alemão visa categorizar e especificar os tipos de agudeza (e não legislar a respeito), contudo torna-se evidente que o vocabulário técnico apresentado resgata os juízos setecentistas. A busca pelos ditos agudos redundaria em consciências vazias e desagradaria àquelas bem fundamentadas, avaliação antropológica que acompanha as configurações do bom gosto desde Muratori, como visto. Vale ressaltar que a noção de belo puro de Kant não pressupõe um conteúdo moral, portanto a relação entre bom gosto e bom senso em suas apreciações estéticas é muito mais tênue do que em qualquer autor que o antecedeu. Assim, à arte bela (incluindo a poesia) não é imprescindível falar a verdade, contudo, a busca vazia pelo atrativo da agudeza é também frívola, os jogos de palavras sem conformidade afins são insípidos. Diante do impacto da teoria kantiana nas discussões estéticas imediatamente ulteriores não é de se espantar, portanto, a perpetuação dessa validação dos juízos setecentistas no que concerne a determinadas práticas identificadas com a potencialidade da agudeza. 


\section{Bom gosto e crítica literária oitocentista}

Tendo em vista o caráter incontornável dessas proposições retóricas ao longo de todo o século XIX, é provável (e verificável) que esse conjunto de categorias tenha sido mobilizado pela crítica literária praticada pelos românticos. Isso se verifica mesmo no contexto de "materiais estéticos avançados” - para abusar de uma expressão de Theodor Adorno -, como poderia ser lida a obra de Álvares de Azevedo. Muito de seu pensamento estético foi dissecado à luz do romantismo alemão e do idealismo de Kant ${ }^{6}$, entretanto há uma passagem bastante clara do ensaio "Literatura e civilização em Portugal” que parece tributária de um modo de ser poético herdeiro da Ilustração:

Quando os hábitos guerreiros dessas duas nações acabarão, a poesia descahio. [...] E emquanto a literatura castelhana se perdia nos trocadilhos e no gongorismo, o monumento das letras portuguesas era a Phenix renascida, typo dos desvarios de mentes caducas. - A Phenix é um objeto digno de estudo: é um padrão do estado vergonho de esfalfamento e laxidão, do afão de um dormir de escrava, dessa pobre Lusitania que a derrota de Alcacer-Quibir e os manjeos do jesuitismo entregarão sem laurea e corôa, aos sorvos sedentos de vida, que lhe bebia no romper das veias o vampyro Castelhano. (AZEVEDO, 1846, p.146).

No trecho Álvares de Azevedo discute a história da literatura da Inglaterra e da Espanha, observando que o século de ouro de Lope de Vega, Quixote e Shakespeare fora marcado pela disputa, enquanto nova conformação da "turba da guerra” formadora de um caráter "homérida”. O momento posterior ao cessar fogo implicaria a ruína da literatura seiscentista de Gôngora e seus “trocadilhos”. Acompanhando Kant e todos os tratadistas setecentistas, essas práticas agudas estariam diretamente relacionadas a uma dificuldade cognitiva. Observa-se entretanto a distância que Azevedo toma em relação aos discursos pragmático-normativos dos tratados, na medida em que a derrocada poética acompanharia certa degeneração histórica das nações, o que daria a ver uma concepção novíssima de filosofia da história, tomada sob um ponto de vista antropológico do desenvolvimento [Bildung] da cultura, que para os limites do presente artigo não caberia esmiuçar.

Azevedo não poderia estar mais distante das formulações moralizantes da Ilustração que fariam coincidir poesia e moral, ou poesia e verdade. Conforme observa Natália Souza Santos, o poeta estaria implicado em posição de vanguarda ao buscar lastro para sua reflexão poética nas formulações estritamente contemporâneas de Théophile Gautier:

o autor parte de um aforismo, "O fim da poesia é o belo", e, na tentativa de asseverar esta posição, num exercício retórico próximo ao do meio acadêmico no qual estava inserido, mas que procura transcendê-lo, ele percorre a tradição, clássica e romântica, apontando a existência da imoralidade em ambas as escolas, justificando, perante a crítica e o público, o possível
${ }^{6}$ Ver por exemplo CUNHA, Cilaine Alves. $O$ belo e o disforme: Alvares de Azevedo e a ironia romântica. São Paulo: EdUSP, 1998 e SANTOS, Natália de Souza. O pensamento crítico de Álvares de Azevedo por meio de seus prefácios: antagonismo e dissolução. Dissertação de Mestrado (Literatura Brasileira), FFLCH, USP, São Paulo, 2012. 
conteúdo imoral do poema prefaciado, e a imoralidade de uma determinada obra, desde que ela fosse bela. (SANTOS, 2012, p. 60).

Lucidamente, Santos demonstra como, ao lançar mão da apropriação da tradição ocidental, Álvares de Azevedo pôde se contrapor às prerrogativas em voga, apregoadas por um Gonçalves de Magalhães, por exemplo (SANTOS, 2012, p. 61). Aproximando-se da sensibilidade moderna, Álvares de Azevedo relê os autores “clássicos” à luz de categorias anacrônicas, propondo novas compreensões de suas obras sem levar em conta seus regimes de elogio e censura conforme compreendidos no gênero epidítico. Assim, a imoralidade de Shakespeare ou Cervantes serve ao mesmo propósito que a imoralidade de Byron, Musset e, por extensão, do próprio autor.

Nesse sentido, a poesia não torna palatável qualquer verdade e por extensão qualquer verdade moral. Os caminhos para a justificação do belo em Azevedo passam por outras determinantes históricas e estéticas, mas, ainda assim, os juízos sobre o estilo seiscentista eivado da agudeza (entendida como vazia) permanecem intactos. Por vias absolutamente diversas, o bom gosto retém algo de seu impacto, ainda que enquanto ruína.

Perpetuação similar se encontra também no tecido crítico de Bernardo Guimarães. Em seu conhecido ensaio Reflexões sobre a literatura brasilei$r a$, o poeta e romancista trata de montar um esquema histórico, certamente tributário de leituras do romantismo alemão (em especial da filosofia de Friedrich Schlegel e, por decorrência, de Herder), no qual propõe uma genealogia da poesia:

Mas assim como a reflexão succede á imaginação, a poesia cede o lugar á philosophia; a arte do calculo e da abstração desseca o sentimento, e apaga a imaginação; ao toque do sceptro severo da razão esvae-se o bello edificio erigido pela ingenua credulidade dos povos primitivos. [...] Entre as nações jovens os poetas são os representantes do genio nacional, seus cantos são a expressão da indole e das crenças populares, nelles legam á posteridade o retracto moral de sua epocha; mas quando as nações envelhecem, a fé e o enthusiasmo se esvaece e ao lado do desenvolvimento intellectual apparece a corrupção moral e o scpeticismo, e os homens que amam apaixonadamente o bello e o sublime não o podendo encontrar no circulo em que vivam, vêem-se forçados a transpor o espaço e o tempo para buscar alimento para sua alma, e emoções para seu coração ou nas ruinas do passado ou nos remotos climas, aonde a civilisação não tem esgotado as fontes da inspiração, tornão-se então entes de uma outra esphera isolada do mundo real; á poesia popular e positiva succede a ideal e transcendente.O Brasil está na quadra em que a poesia é a propriedade do povo, e manifesta-se por si mesma; [...]. (GUIMARÃES, 1847, v. 1 p. 14-15).

No trecho, destaca-se a percepção compartilhada com Herder da descrença no progresso natural, certo e linear da humanidade. O desenvolvimento (Bildung) natural da civilização teria seus limites, dada a imprevisibilidade 
da marcha histórica. Assim, quando o progresso natural falha, é necessária a força ativa de um desenvolvimento artificial (cultural) que possa tracejar novas rotas.

Seguindo a teoria do filósofo, ao longo da história humana as duas linhas de força concorreram até o triunfo da aculturação artificial (Bildung) característico da modernidade. Como o próprio argumento de Bernardo Guimarães, a religião seria o processo embrionário do artificialismo cultural que tenta reconduzir a Bildung a partir de um momento de decadência da potência natural de desenvolvimento. Nesse sentido, a religião seria um processo artificial que visa fazer vicejar novamente o passado, após o severo toque da razão e da filosofia. Assim, assumindo certa ingenuidade do desenvolvimento nacional, Guimarães enxerga prejuízo na imitação de modelos europeus, precisamente em razão do desnível entre a situação moral e intelectual das duas civilizações (europeia e americana). Desse modo, a translação da poesia francesa causaria uma "madurez forçada" que amargaria os frutos poéticos da terra. Para tanto, em sua defesa, a poesia brasileira deveria trabalhar da emanação da sabedoria popular “pré-filosófica”, é possível dizer. De modo que poesia e verdade estariam indissociadas. A poesia telúrica é verdade, mas não a verdade da ciência, o que implicaria dizer que a poesia não está a serviço da verdade. Assim, acompanhando Azevedo, Bernardo mobiliza uma filosofia da história para libertar a poesia de sua função didática vassalar.

Ainda assim, em suas apreciações críticas da poesia particular dos contemporâneos, Guimarães é frontalmente refratário à agudeza e ao gongorismo. A questão da "manufatura” das imagens aparece em textos críticos de Guimarães da década de 60 do século XIX quando foi articulista regular do periódico A atualidade (1859-1864), conforme elucida o resgate de fontes primárias, levado a cabo por Ednaldo Gomes (2007). Guimarães, em dois momentos, condena a produção de imagens aberrantes em seus contemporâneos, Gonçalves Dias e Junqueira Freire. Sobre os versos “Doce poeira de aljofradas gotas,/Ou pó sutil de pérolas desfeitas” de Os timbiras de Gonçalves Dias, afirma Bernardo:

O epíteto - doce - é uma inconcebível transgressão, já não diremos do bom gosto, mas até parece que de bom senso. Poeira doce é cousa que nenhum paladar pode tragar. Aqui anda refinado gongorismo, ou cousa que o valha. (GUIMARÃES apud GOMES, 2007; p. 191).

Os pressupostos enunciativos da crítica jocosa incluiriam a reafirmação do bom gosto setecentista contra o “refinado gongorismo”, isto é, o estilo agudo do Seiscentos de metáforas fantasiosas que correm como um cavalo fogoso (para falar com Cândido Lusitano) que produziria uma espécie de máximo afastamento da imitação da natureza ao interpor como que biombos - metáfora da metáfora -, aproximando elementos muito díspares na 
linearidade da dicção. Bernardo é, ele mesmo agudo, ao afirmar que "gosto" nenhum pode tragar a doçura, na medida em que esta nada contribui para dar inteligibilidade à imagem da poeira. Segundo o critério setecentista, o epíteto não vivifica os contornos do objeto produzindo uma "semelhança de si”. Mas apenas dá a ver uma forma impossível e inapreensível pela mente do leitor/ouvinte. Em outro texto, acerca da poética de Junqueira Freire, o critério de avaliação se clarifica:

Entretanto Junqueira Freire, que tinha tão belos arrojos de imaginação, que possuía tão favoráveis disposições da natureza, já tinha o gosto pervertido pela maléfica influência de uma escola, que de há muito existe entre nós; caracterizar e definir essa escola é tarefa bem difícil; se falássemos à nação francesa, cujo espírito engenhoso tem criado expressões para explicar todas as aberrações do gosto, todos os desvarios da imaginação, chamá-la-íamos a escola, do - galimatias. O galimatias é uma espécie de estilo cheio de imagens vagas, confusas, ininteligíveis, que parecendo dizer alguma cousa nada significam; - é uma espécie de anfiguri.

Desse estilo infelizmente anda envasada toda a nossa literatura moderna; é um vicio, a que não tem escapado os nossos melhores poetas. Os Srs. Porto-Alegre e Gonçalves Dias, a cada passo nos fornecem exemplos de galimatias. O galimatias não é o gongorismo, esse gosto de subtilezas e trocadilhos, que teve sua origem na Itália, e se derramou pela França, Espanha e Portugal antes do século de Luiz XIV; mas tem com ele alguma afinidade, e não deixam de confundirse às vezes. Comparações vagas e mui remotas, metáforas sem propriedades, um extraordinário abuso de alegorias, sempre obscuras e alambicadas, excentricidade e idéias, que roça pelo disparate, eis os traços mais salientes da escola do galimatias. ( GUIMARÃES apud GOMES, 2007, p. 202-203).

A partir do cotejo da produção crítica de Guimarães, compreende-se a recusa por essa poética do "galimatias" fundada no disparate imagético que já fora anteriormente exorcizado pelo século XVIII. A concepção do “jogo”, da "sutileza de trocadilhos” implica a inversão de toda a argumentação pautada pela hierarquização do uso do ornamento a partir do Iluminismo que persiste em Kant. Isto é, tomar como essencial o contingente, como central o subsidiário e periférico, obnubilar o horizonte do propriamente "poético" em prol do "fantástico" que deforma a forma cujos liames deveriam ser bem evidentes para o leitor.

Como visto, o poético deve ser prenhe da verdade histórica que acompanhe a ingenuidade da terra brasílica e assim cantar, com simplicidade, as coisas da gente e da terra. Em segunda instância, portanto, a poesia do galimatias torna-se portadora de malefícios à Bildung na medida em que imita uma prática estrangeira de outro tempo (de “antes do século de Luiz XIV”, isto é, o Século XVII) sem encontrar qualquer enraizamento na pátria. Uma vez mais, por vias historicistas se rechaça também a frivolidade da agudeza em defesa de um "bom gosto". 
Entre o periodismo acadêmico do século XIX se podem verificar, à abundância, concepções de poesia que caminham muito próximas das prerrogativas civilizatórias setecentistas, de modo mais ortodoxo que as impressões modernizantes de Álvares de Azevedo e Bernardo Guimarães. Em texto não assinado publicado no periódico Ensaios Literários em 1848, lê-se nota lastimosa quanto à extinção da revista Violeta: "É agradavel o ver-se o gosto litterario desenvolvendo-se entre nós, pois a literatura é a bitola por onde mede a civilização de um povo: ella ameniza e adoça os costumes, incutindo nos corações o amor do belo, e o desejo de imital-o” (ANÔNIMO, Número 2 de 1848, p. 47). Em franca continuidade às discussões de Verney, a poesia é associada à dominação de uma natureza selvagem e ao modelar de um corpo cívico que se apegasse, pelo viés imitativo, a um conjunto de costumes francamente associados à sobrevalorização da instrução. Exatos cem anos depois, o deleite da literatura ainda presta-se à instrução e ao convencimento do corpo social.

O hoje desconhecido Pedro Fernandes, de modo similar, publica na seção “Literatura” dos Ensaios Literários do Ateneu Paulistano severa apreciação dos artefatos culturais do século de ouro espanhol:

A Hespanha herdou a imaginação do Arabe, a crusada dos sete - séculos contra os Sarracenos arraigou em seu espirito o servilismo Religioso; veio depois o D. Quixote com a lança da cavalaria, symbolisou o ultimo delírio no domínio das expedições, e com o cerebro desvairado pronunciou um sarcasmo á influencia da imaginação. (1861, edição 4, p. 77).

A má eloquência aqui se associa ao obscurantismo religioso e aos excessos imaginativos que deveriam ser podados em prol do cultivo retilíneo e nítido da verdade científica. Comungando com Álvares de Azevedo de um anticlericalismo, Pedro Fernandes vê na injunção do pensamento religioso o vetor de decadência servil da literatura. $\mathrm{O}$ que se pode verificar é que as diversas revistas acadêmicas que circularam em meados do século XIX parecem traduzir, já em sua proposta basilar de produção, um vínculo indissociável entre literatura e verdade. De fato, a partilha de argumentos comuns entre os acadêmicos de Direito, principais articulistas desses periódicos, parece tracejar um contínuo entre poesia e saber, literatura e ciência, que já se observa pela nomeação das associações e seus respectivos periódicos. O Acayaba, contemporâneo dos outros títulos citados, possuía como proposta e subtítulo “Jornal Scientifico e Litterario”. Em comunhão a tal procedimento, não raro leem-se em tais revistas discursos elogiosos às sociedades científicas do período que "espelhão ilustração no meio do povo, soccorrem os estados, e constituem a gloria, e o orgulho das nações”. (Revista Mensal do Ensaio Philosóphico Paulistano, Edição 2, 1852, p. 21).

Assim, Bernardo Guimarães e Álvares de Azevedo, mesmo em sua proposta original, não ficariam imunes às discussões da utilidade poética 
conforme propostas pela realidade discursiva circundante. Tendo em vista que seus textos também foram veiculados pelos mesmos periódicos citados - em especial, nos Ensaios Literários -, a defesa da poesia passa necessariamente por uma resposta ou reconfiguração de uma longa e durativa ideia de bom gosto que parece ter feito extensa carreira nas letras nacionais no momento de sua fundamentação.

\section{Referências}

ACÍZELO, Roberto. O império da eloquência: retórica e poética no Brasil oitocentista. Rio de Janeiro: Editora da Universidade Estadual do Rio de Janeiro, 1999.

AZEVEDO, Álvares. Obras, Tomo Segundo - Prosa. 3. ed. Rio de Janeiro: Garnier, 1846. 3 v

BLAIR, Hugh. Lectures on Rhetoric and Belles Lettres. 3. ed. London: A. Stratha; T. Cadell, 1787.

CARVALHO, Francisco Freire de. Lições elementares de eloquência nacional. Lisboa: Typographia Rollandiana, 1840.

nacional. Lisboa: Typographia Rollandiana, 1851.

Lições elementares de poética

CUNHA, Cilaine Alves. O belo e o disforme: Alvares de Azevedo e a ironia romântica. São Paulo: EDUSP, 1998.

ENSAIOS LITTERARIOS. São Paulo: Typographia do Governo (Palácio), 1847-1850.

ENSAIOS LITTERARIOS DO ATHENEO PAULISTANO. São Paulo: Typographia Liberal, Literária, Dois de Dezembro, Imparcial, 1852-1859.

FREIRE, Francisco José (Cândido Lusitano). Arte poética ou Regras da verdadeira poesia em geral, e de todas as suas especies principaes, tratadas com juízo crítico. 2. ed. Lisboa: Na. Offic. Patricial Francisc. Luiz Ameno, 1759.

FREIRE, Junqueira. Elementos de retórica nacional. Rio de Janeiro: Eduardo e Henrique Laemmert, 1869.

FURTADO, Joaci Pereira. “Os Almotacéis do Bom Gosto: a boa poesia no Setecentos português, segundo ela mesma” Revista História. São Paulo: Universidade Estadual Júlio Mesquita, v. 36, n. 20, 2017.

GOMES, Ednaldo Cândido. Sutilezas e mordacidades na poética de Bernardo Guimarães. 2007. Dissertação (Mestrado em Letras) Pontifícia Universidade Católica de Minas Gerais, Belo Horizonte, 2007. 
GUIMARÃES, Bernardo. "Reflexões sobre a literatura Brasileira” em Ensaios Literários. São Paulo: Typographia do Governo (Palácio), 1847. v. 1, p. 14-15HONORATO, Manuel da Costa. Sinopses de eloquência e poética nacional. Rio de Janeiro: Typographia Americana, 1870.

KANT, Immanuel. Anthropology, history and education. Günter Zöller and Robert B. Louden (Org.); Tradução de Mary Gregor, Paul Guyer, Robert B. Louden, Holly Wilson, Allen W. Wood, Günter Zöller and Arnulf Zweig. Cambridge University Press, 2007.

. Crítica da Faculdade do Juízo. Tradução de Valerio Rohden e António Marques. 2. ed. São Paulo: Forense Universitária, 2008.

Lecciones de Antropología: Fragmento de estética y antropología. Org e trad: Manuel Sánchez Rodríguez. Granada: Editorial Comares, 2015.

MARTINS, Eduardo Vieira. A fonte subterrânea: o pensamento crítico de Alencar e a retórica oitocentista. 2003. Tese (Doutorado em Teoria e História Literária) - Instituto de Estudos da Linguagem, UNICAMP, Campinas, 2003.

MURATORI, Ludovico. Da perfeita poesia. Em: ACİZELO, Roberto (Org.). Do Mito das Musas à Razão das Letras: Textos Seminais para os Estudos Literários (século VIII A.C. - Século XVIII). Santa Catarina: Argos, 2014, p. 370-80.

REVISTA LITTERARIA DO JORNAL DO ENSAIO FILOSOFICO PAULISTANO. São Paulo: Typographia Liberal, 1851-1852.

REVISTA MENSAL DO ENSAIO FILOSOFICO PAULISTANO. São Paulo: Typographia Liberal e Imparcial, 1852-1864.

SANTOS, Natália de Souza. O pensamento crítico de Álvares de Azevedo por meio de seus prefácios: antagonismo e dissolução. 2012. Dissertação de (Mestrado em Teoria Literária e Literatura Comparada ) - Faculdade de Filosofia, Letras e Ciências Humanas, Universidade de São Paulo, São Paulo, 2013.

VERNEY, Luís Antônio. Verdadeiro método de estudar: para ser útil à República, e à Igreja: proporcionado ao estilo, e necessidade Portugal. Valensa: Oficina de Antonio Balle, 1746.

Recebido em agosto/2018.

Aceito em dezembro//2018. 